Chirurgia (2018) 113: 558-563

No. 4, July - August

Copyright@ Celsius

http://dx.doi.org/10.21614/chirurgia.113.4.558

\title{
A Staged Strategy for Early Abdominal Wall Closure in a Case Involving Ruptured Abdominal Aortic Aneurysm Requiring Open Abdomen in Which Primary Fascial Closure was Difficult to Achieve: A Case Report
}

\author{
Masatoku Arai, Shiei Kim, Hiroyuki Yokota \\ Department of Emergency \& Critical Care Medicine, Nippon Medical School, Tokyo, Japan
}

Corresponding author:

Masatoku Arai, M.D., Ph.D. Department of Emergency \& Critical

Care Medicine, Nippon Medical

School, Tokyo, Japan

E-mail: amasatoku@nms.ac.jp

\section{Rezumat}

Management etapizat pentru închiderea timpurie a peretelui abdominal intr-un caz cu anevrism aortic abdominal rupt și cu o închidere fascială primară dificil de realizat în urma chirurgiei abdominale deschise: prezentare de caz

Laparotomia este uneori necesară pentru a salva viața pacienților cu anevrism aortic abdominal rupt. Acest articol prezintă un caz în care a fost aplicat un management etapizat pentru închiderea peretelui abdominal şi prevenirea posibilelor complicații severe datorate perioadei mari de timp în care abdomenul a fost deschis. Un pacient în vârstă de 81 de ani cu anevrism aortic abdominal rupt a fost transportat la spitalul nostru. După prima intervenție chirurgicală, care a necesitat efecutarea laparotomiei, edemul visceral prelungit şi hematomul retroperitoneal au făcut ca închiderea fascială primară să fie dificilă. Pentru a reduce defectul parietal abdominal s-a utilizat o substituție cu meşă şi apoi a fost aplicată terapia cu presiune negativă utilizată în tratamentul plăgilor. Cu toate acestea, închiderea fascială primară nu a putut fi realizată, iar reconstrucția peretelui abdominal a fost efectuată folosind metoda lamboului rotit format din teaca anterioară a ambilor muşchi drepți abdominali. Mai mult, defectul tegumentar extins de la nivelul peretelui abdominal a făcut imposibilă realizarea suturii primare. Aşadar, a fost utilizat un lambou bipediculat. Pacientul a fost transferat la un alt spital, fără să prezinte complicații deosebite. În cazul prezentat, aplicarea unui management etapizat de închidere a peretelui abdominal, bazat pe 
durata deschiderii abdomenului, starea fasciei parietale abdominale şi tegumentului abdominal, a fost considerat important pentru realizarea definitivă a soluției de continuitate abdominală şi prevenirea complicațiilor severe.

Cuvinte cheie: anevrism aortic abdominal rupt, terapia cu presiune negativă a plăgilor, laparotomie, metoda lamboului răsturnat format din teaca muşchiului abdominal bilateral anterior, lambou bipediculat

\begin{abstract}
Open abdomen is sometimes necessary to save lives after ruptured abdominal aortic aneurysm repair. We report a case in which a staged strategy for early abdominal wall closure was applied to prevent the severe complications due to the extended period of open abdomen. An 81-year-old man with ruptured abdominal aortic aneurysm was transported to our hospital. After the first operation, which required open abdomen, prolonged visceral edema and retroperitoneal hematoma made primary fascial closure difficult. Mesh mediated fascial traction was undergone to reduce the gap in fascial dehiscence under negative pressure wound therapy. However, primary fascial closure could not be accomplished, and abdominal wall reconstruction was performed using bilateral anterior rectus abdominis sheath turnover flap method. Moreover, the skin along the abdominal wall was too tight to be closed primarily. Thus, a bipedicled skin flap was applied. The patient was transferred to another hospital without any remarkable complications. In the present case, the application of a staged closure strategy, which was based on the duration of open abdomenand the condition of the fascia and skin was considered to be important for achieving definitive abdominal closure and preventing the severe complications.
\end{abstract}

Key words: ruptured abdominal aortic aneurysm, negative pressure wound therapy, open abdomen, bilateral anterior rectus abdominis sheath turnover flap method, bipedicled skin flap

\section{Introduction}

Open abdomen after ruptured abdominal aortic aneurysm (RAAA) repair is sometimes necessary to save lives $(1,2)$. However, in RAAA patients requiring OA, it is sometimes difficult to achieve early primary fascial closure due to prolonged visceral edema, retroperitoneal hematoma and the lateralization of the abdominal musculature (1-3). An extended period of OA may results in severe complications, such as intra-abdominal abscess, intestinal fistula, graft infection, and large ventral hernia (1-3). We describe a case in which a staged strategy for abdominal wall closure was applied in the early phase of OA to prevent severe complications.

\section{Case Report}

An 81-year-old man was transported to our hospital in an ambulance and resuscitated for shock due to RAAA. Computed tomography showed an infrarenal aneurysm of approximately $5.6 \mathrm{~cm}$ in diameter with a massive retroperitoneal hematoma (Fig. 1). Although the patient had undergone emergency open repair, vigorous resuscitation was required during the operation. The abdomen could not be closed to prevent the development of ACS as a result of severe visceral edema and retroperitoneal hematoma (Fig. 2A). The abdomen was left open after the first laparotomy, and negative pressure wound therapy (NPWT) was applied as temporary abdominal 


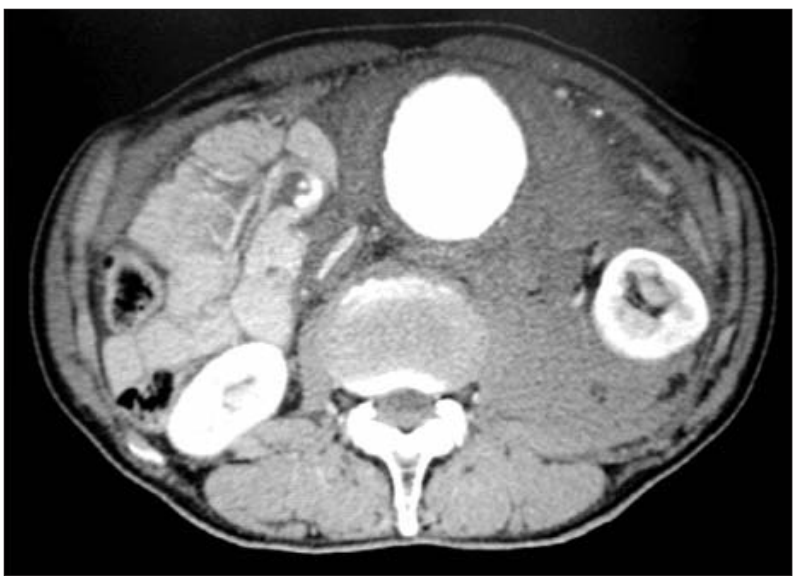

Figure 1. CT scans of the abdomen on admission. CT scans showed an aneurysm approximately $5.6 \mathrm{~cm}$ in diameter with a massive retroperitoneal hematoma and the small bowel pushed the right side of the abdominal cavity closure (Fig. 2B). Because early primary fascial closure could not be achieved, mesh mediated fascial traction, as reported by Petersson et al. (4), was applied on postoperative day (POD) 4 (Fig. 2C). Polypropylene mesh (Gynecare Gynemesh ${ }^{\mathrm{TM}}$ PS 25 x $25 \mathrm{~cm}$, Ethicon Inc, Johnson \& Johnson, USA) was divided into two halves and sutured to the bilateral fascia with a polypropylene running suture. A perforated intestinal isolation bag was placed over the abdominal contents under the mesh to protect the bowel from the injury and adhesion due to contact with the mesh, and the mesh halves were sutured together with a polypropylene running suture in the midline to reduce the gap between the fascial edges (Fig. 2D). Polyurethane foam was placed on top between the abdominal wall edge, and

Figure 2. View of the abdomen and NPWT after the first operation, and view of meshmediated fascial traction.

(A) View of the abdomen after the first operation for RAAA. (B) Polyurethane form was placed over the abdominal wall. The form was sealed by an occlusive selfadhesive drape, and NPWT was applied after the first operation. (C) Polypropylene mesh (Gynecare Gynemesh ${ }^{\mathrm{TM}}$ PS $25 \times 25 \mathrm{~cm}$, Ethicon Inc, Johnson \& Johnson, USA) was sutured to the fascial edges with running polypropylene sutures to reduce the distance between the edges on POD 4. (D) The mesh was tightened with a running suture after covering the viscera with a perforated intestinal isolation bag, while applying tension on the fascia to reduce the separation of the fascial edges, after which NPWT was continued.

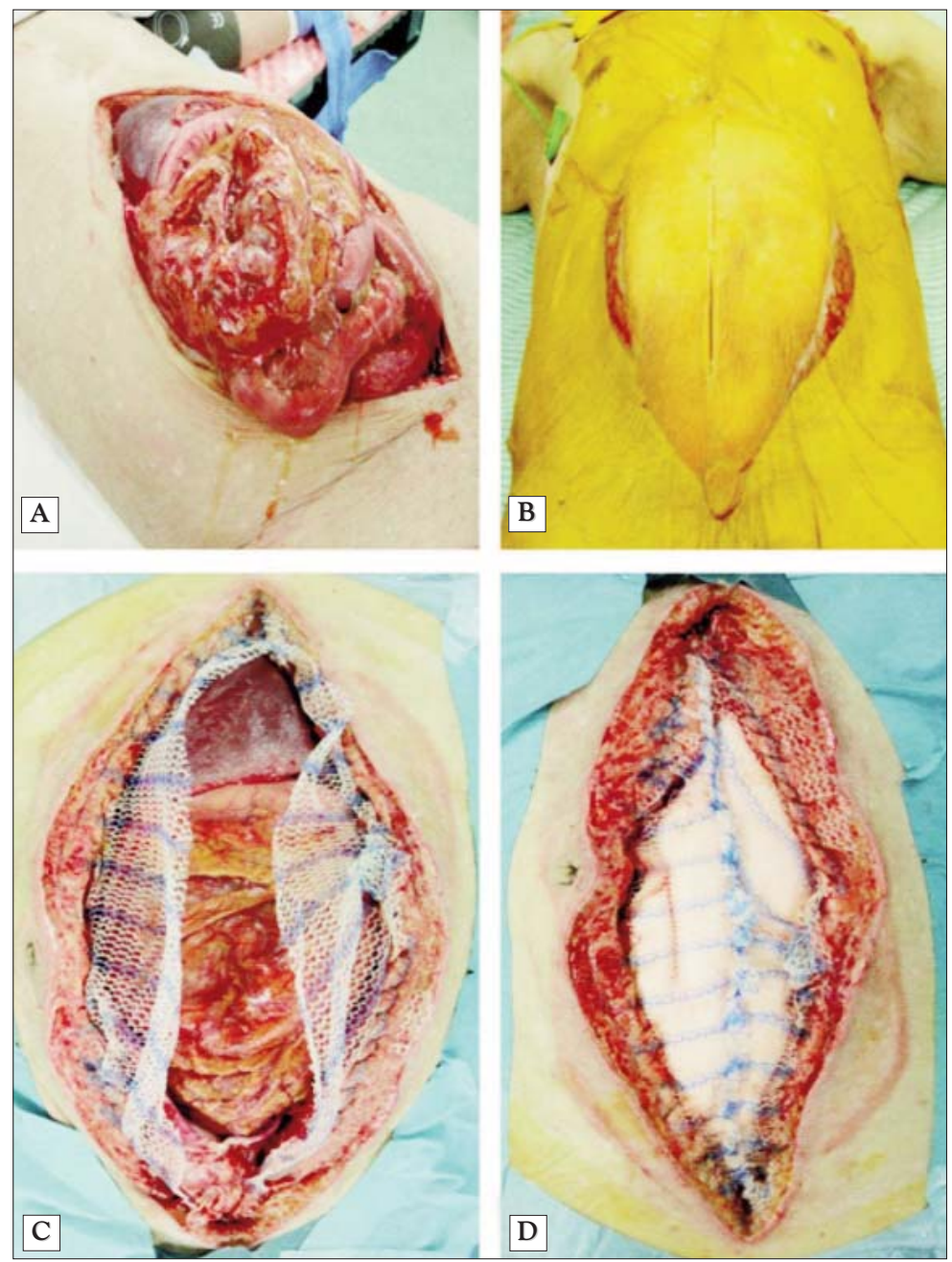


NPWT was continued,with the dressing changed every two to three days. The mesh halves were re-sutured together with tightening at the time of each dressing change of NPWT. Since primary fascial closure could not be achieved on POD 8 (Fig. 3A), the mesh was removed and abdominal wall reconstruction was performed using bilateral anterior rectus abdominis sheath turnover flap method (Turnover flap method), as previously reported (5) to prevent complications, especially graft infection. Briefly, the skin and adipose tissue were undermined from the anterior rectus sheath (Fig. 3B). Turnover flaps were made by longitudinal incisions along the lateral edge of the anterior rectus sheath (Fig. 3C), which were finally closed at midline with interrupted sutures (Fig. 3D). However, despite of the undermining of the skin and adipose tissue from the anterior rectus sheath, the skin was too tight to be closed primarily. Polyurethane form was therefore placed over the turnover flaps, and NPWT was continued. Since the skin along the abdominal wall still remained too tense for the dehiscence to be closed medially (Fig. 4A), a bipedicled skin flap (6) was applied on POD 16. In brief, a bipedicled skin flap of approximately $29 \times 14 \mathrm{~cm}$ in size was elevated from the right side of the abdominal wall and completely tension-free midline closure was achieved (Fig. 4B), after which the incisional areas were subsequently covered with split-thickness skin grafts. The patient was transferred to another hospital on POD 61 without any remarkable complications. No signs of ventral hernia were evident at 28 months after surgery (Fig. $4 C, D$ ).

\section{Discussion}

Since ACS was first described by Kron et al. in 1984 (7), RAAA has been considered to be at a significant risk factor for ACS $(1,2,7)$. The development of ACS has been shown to cause hypoperfusion syndrome leading to progressive multiple organ failure and to be frequently fatal $(1-3,7)$. The most effective treatment for ACS is immediate decompressive laparotomy when primary fascial closure is undertaken during the first operation (1-3). Recently, the use of prophylactic OA in the first operation was reported to prevent postoperative ACS in the patients with $\operatorname{RAAA}(1,2,4,7,8)$.

However, it has also been reported that it can be difficult to achieve primary fascial closure after more than 7-14 days in OA patients

Figure 3. Intraoperative view of the turnover flap method on POD 8.

(A) The degree of separation of the fascial edges was approximately $6 \mathrm{~cm}$ before procedure with the turnover flap. (B) The skin and adipose tissue were separated from the anterior rectus sheath. (C) The turnover flaps were created by making longitudinal incisions along the lateral edge of the anterior rectus sheath, which were subsequently mobilized medially. (D) The turnover flaps were approximated with interrupted sutures

A
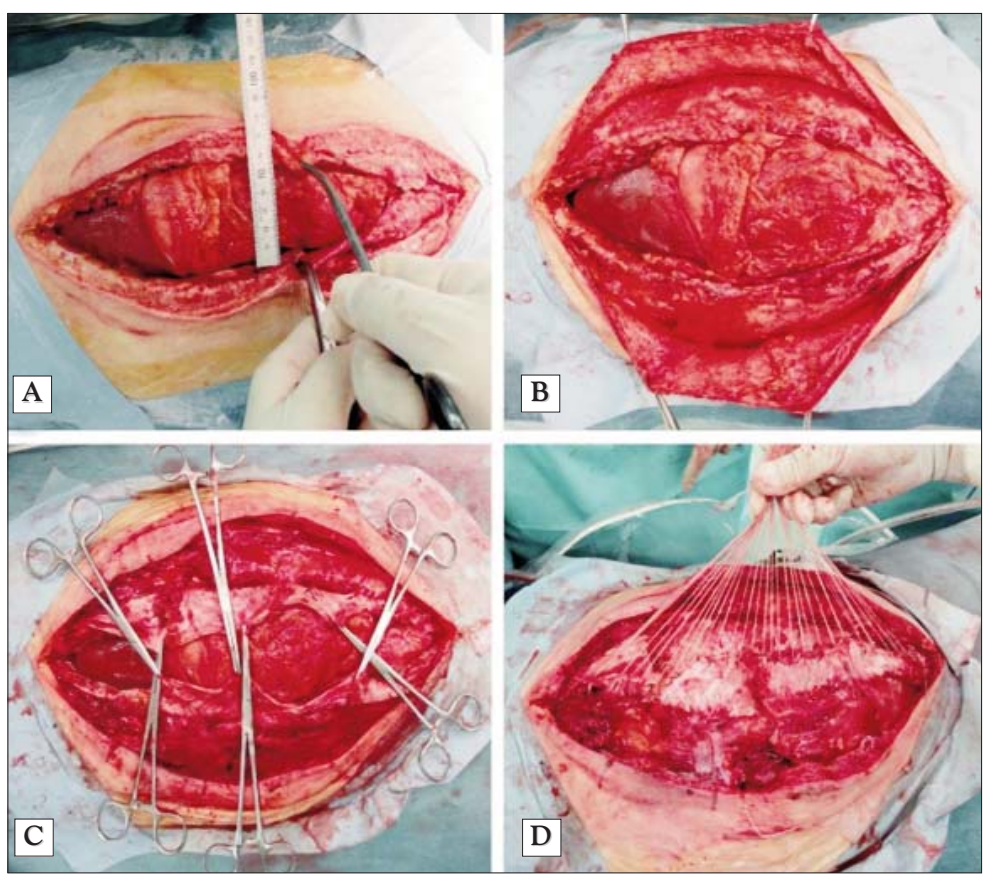
Figure 4. Intraoperative view of the bipedicled skin flap and view of the abdominal wall postoperatively. A bipedicled skin flap was applied on POD 16.

(A) View of the abdomen before the procedure with the bipedicled skin flap. Achieving skin closure was difficult. (B) The bipedicled skin flap was elevated from the right side of the abdominal wall and tension-free midline closure was achieved. The incisional areas were subsequently covered with split-thickness skin grafts. (C) Anteroposterior view; (D) Lateral view in the sitting position at 28 months after surgery.Although a slight lower abdominal bulging could be observed in both views, the signs of abdominal hernia could not be seen

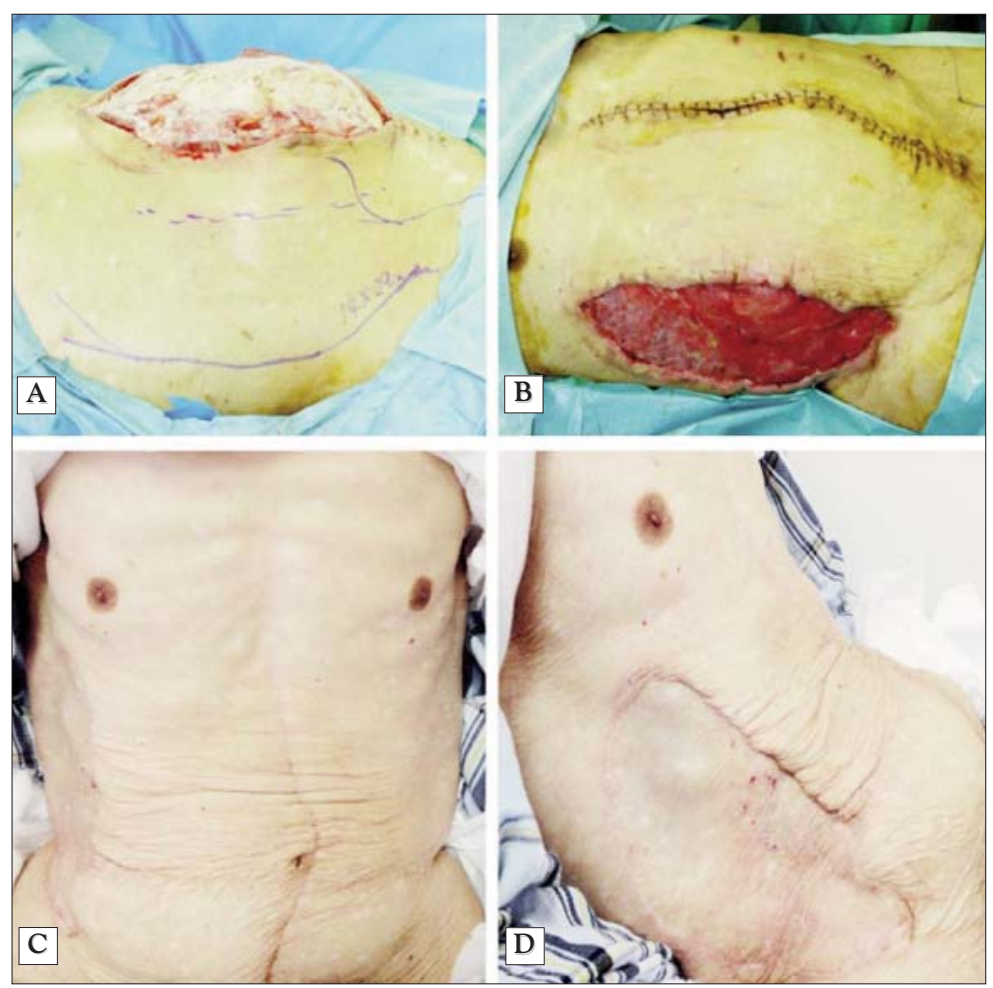

because of the lateralization of the abdominal musculature $(3,8)$. Although OA facilitates the prevention of ACS, prolonged periods of OA are associated with serious complications, such as intra-abdominal abscess, intestinal fistula, graft infection, and large ventral hernia (1-3, 7, 8, 9). Taken together, in RAAA patients, it is not only necessary to perform OA to prevent the development of ACS, but it is even more important to shorten the period of OA by achieving early abdominal closure as soon as possible after the patient's physiological derangement has recovered, in order to avoid infectious complications, including prosthetic graft infection $(1,2,7)$.

Petersson et al. first demonstrated that the combined use of NPWT and mesh mediated fascial traction was effective in cases associated with the long periods of OA with difficulty in primary fascial closure by NPWT alone (4). In a prospective study on the application of this combined method in the treatment of trauma and non-trauma patients, the primary fascial closure rate among the survivors was reported to be $89 \%$ (8). It was also reported that incisional midline hernia occurred in about $60 \%$ of patients at one year of follow-up; however, most these cases were asymptomatic (9). In the present case, the primary fascial closure could not be accomplished by this combined method on POD 8. Thus, turnover flap method reported by Kushimoto et al. was employed to achieve early abdominal wall reconstruction (5). It was reported that no severe complications, such as abscess, intestinal fistula occurred, or abdominal wall hernia were observed among survivors during short- and mid-term follow-upperiods (5). However, since the skin along the newly reconstructed abdominal wall was too tight for primary closure, a bipedicled skin flap (6) was applied. Thus, a staged strategy for early abdominal wall closure from fascia to skin using different surgical procedures might be effective for avoiding the risk of the severe complications in patients with RAAA requiring OA.

\section{Conclusion}

In the present report, we described a staged strategy for early abdominal wall closure. This 
strategy may be effective for preventing severe complications in RAAA patients requiring $\mathrm{OA}$ in whom primary fascial closure is difficult to achieve.

\section{Conflicts of Interest and Source of Funding:}

None.

\section{References}

1. Acosta S, Seternes A, Venermo M, Vikatmaa L, Sörelius K, Wanhainen A, et al. Open Abdomen Therapy with Vacuum and Mesh Mediated Fascial Traction After Aortic Repair: an International Multicentre Study. Eur J Vasc Endovasc Surg. 2017; 54(6):697-705

2. Acosta S, Wanhainen A, Björck M. Temporary Abdominal Closure After Abdominal Aortic Aneurysm Repair: A Systematic Review of Contemporary Observational Studies. Eur J Vasc Endovasc Surg. 2016;51(3):371-8.

3. Regner JL, Kobayashi L, Coimbra R. Surgical strategies for manage- ment of the open abdomen. World J Surg. 2012;36(3):497-510.

4. Petersson U, Acosta S, Björck M. Vacuum-assisted wound closure and mesh-mediated fascial traction - a novel technique for late closure of the open abdomen. World J Surg. 2007;31(11):2133-7.

5. Kushimoto S, Yamamoto Y, Aiboshi J, Ogawa F, Koido Y, Yoshida R, et al. Usefulness of the bilateral anterior rectus abdominis sheath turnover flap method for early fascial closure in patients requiring open abdominal management. World J Surg. 2007;31(1):2-8; discussion 9-10.

6. Zaccara A, Zama M, Trucchi A, Nahom A, De Stefano F, Bagolan P. Bipedicled skin flaps for reconstruction of the abdominal wall in newborn omphalocele. J Pediatr Surg. 2003;38(4):613-5.

7. Bozeman MC, Ross CB. Intra-Abdominal Hypertension and abdominal compartment syndrome in association with ruptured abdominal aortic aneurysm in the endovascular era: Vigilance Remains Critical. Crit Care Res Pract. 2012;2012:151650.

8. Acosta S, Bjarnason T, Petersson U, Pțtsson B, WanhainenA, Svensson M, et al. Multicentre prospective study of fascial closure rate after open abdomen with vacuum and mesh-mediated fascial traction. Br J Surg. 2011;98(5):735-43.

9. Sörelius K, Wanhainen A, Acosta S, Svensson M, Djavani- Gidlund $\mathrm{K}$, Björck M. Open abdomen treatment after aortic aneurysm repair with vacuum-assisted wound closure and mesh-mediated fascial traction. Eur J Vasc Endovasc Surg. 2013;45(6):588-94. 